\title{
逆ダイナミクス法と PI 制御を用いた速度距離制御系設計*1 A Velocity and Distance Control System Synthesis Using Dynamic Inversion with PI Control
}

\author{
榎 本 圭 祐*2 $\cdot$ 山 崎 武 志*2. 高 野 博 行*2 . 馬 場 順 昭*3 \\ Keisuke Enomoto, Takeshi Yamasaki, Hiroyuki TAKAno and Yoriaki BaBA
}

Key Words : Velocity and Distance Control, Dynamic Inversion, PI Control, UAV

\begin{abstract}
The purpose of this paper is to introduce a velocity and distance control system for leader-following UAVs. In our previous paper, we already proposed a velocity and distance control system, but the system has a problem of "offsets" due to aerodynamic errors and/or leader trajectories. So in this paper, in order to eliminate the offset, a new approach of the velocity and distance control design is introduced. Simulation results show that the proposed velocity and distance control system provides a good performance and there are no offsets.
\end{abstract}

\section{1. 序論}

近年, 無人航空機の発展は目覚ましく, その用途は監視, 偵察，農薬散布，気象観測等，様々な分野に広がっており， その制御の研究も盛んである. 特に, 空中給油等1) の追随 飛行においては, 距離を重視しなければならないが, その ためには速度距離制御が重要である。著者らは前論文 ${ }^{2)}$ おいて, 誘導部には単純追尾航法3)を用い, 制御部には逆 ダイナミクス法 ${ }^{4 \sim 8)}$ と比例制御を用いた追随飛行制御系を 提案し, 特に速度と距離制御系のゲイン決定法について詳 細に論じた。しかし，文献 2)に述べた速度距離制御では, 空力誤差が存在し完全な逆システムを構成できない場合や, 目標機が定加速度運動はもちろん, 定常旋回等の運動をす る場合には定常偏差が生じ, 望ましい相対距離を維持でき ない.

そこで，本論文では，このような場合の定常誤差を除去 するために，前論文において提案した制御系に積分器を付 加することとし，そのときの制御ゲインの決定法を明らか にする。誘導制御系の概略, 単純追尾航法や逆ダイナミク ス法の概要については文献 2)に述べ, 逆ダイナミクス法の 概要については文献 9)にも述べたので本稿では割愛し, 距 離に関する積分器を付加した速度距離制御系の設計法およ びゲイン決定法について詳述した後, シミュレーション結 果を示す.

\section{2. 運動方 程 式}

本論文における記号と表記法の定義を第 1 表に, 機体軸 座標系の定義を第 1 罒にそれぞれ示す。これより，6自由

\footnotetext{
*1 C) 2010 日本航空宇宙学会

平成 22 年 4 月 6 日原稿受付

*2 防衛大学校

*3 防衛大学校名誉教授
}

度剛体航空機の, 並進運動の運動方程式は式 $(1) \sim(3)$ で表 される。

$$
\begin{aligned}
& \dot{u}=r v-q w-g \sin \theta+\frac{q_{t} S}{m} C_{x, t}+\frac{F_{T}}{m} \\
& \dot{v}=p w-r u+g \cos \theta \sin \phi+\frac{q_{t} S}{m} C_{y, t} \\
& \dot{w}=q u-p v+g \cos \theta \cos \phi+\frac{q_{t} S}{m} C_{z, t}
\end{aligned}
$$

\section{3. 誘 導 制 御 系}

本論文における速度制御の位置づけを明確にするため, 本研究において設計した誘導制御系全体の概略図を第 2 図 に示す。第 2 図において誘導部では, 目標機と追従機の位 置関係から単純追尾航法を用いて追随に必要な誘導力を算 出し, 算出した誘導力を発生させるための迎角, 横滑り角, バンク角の各指令值 $\alpha_{d}, \beta_{d}, \phi_{d}$ を決定する. これらの指 令值が, 制御部内の, 逆ダイナミクス法を用いて設計した 姿勢制御の入力值となっている. 姿勢制御には, 第 3 図に示 されるような特異摂動法を併用した逆ダイナミクス法 ${ }^{10,11)}$ を用いている。また, 追従機は, 姿勢制御系の他, 衝突を 避け目標機と一定距離を保つために速度制御系を有してお り，本論文では，この速度制御系を扱う。速度制御系では， 目標機の位置および速度情報を用いて速度に関する逆シス テムから推力の制御量を決定する ${ }^{2,8,9)}$. この速度制御系の 設計手法とゲイン決定法について，次に述べる.

\section{4. 速度距離制御}

本研究において, 逆ダイナミクス法によって設計した姿 勢制御系 10,11$)$ の収束は，単純追尾航法による誘導系の収束 よりも速くなるように設計している2). また，一般に速度の 応答は, 前述の進行方向や姿勢に関する誘導制御系の応答 よりも遅い2)。さらに, 単純追尾航法では, 誘導の結果, 追 
第 1 表 記号と表記法

\begin{tabular}{ll}
\hline \multicolumn{1}{c}{ 記号 } & \multicolumn{1}{c}{ 意 味 } \\
\hline$C_{x, t}, C_{y, t}, C_{z, t}$ & 空力係数 \\
$F_{T}$ & 推力 $[\mathrm{N}]$ \\
$g$ & 重力加速度 $\left[\mathrm{m} / \mathrm{s}^{2}\right]$ \\
$m$ & 機体質量 $[\mathrm{kg}]$ \\
$p, q, r$ & 機体軸角速度成分 $[\mathrm{rad} / \mathrm{s}]$ \\
$q t$ & 動圧 $\left[\mathrm{N} / \mathrm{m}^{2}\right]$ \\
$R$ & 追従機と目標機の相対距離 $[\mathrm{m}]$ \\
$S$ & 翼面積 $\left[\mathrm{m}^{2}\right]$ \\
$u, v, w$ & 機体軸速度ベクトル成分 $[\mathrm{m} / \mathrm{s}]$ \\
$V$ & 機体速度 $[\mathrm{m} / \mathrm{s}]$ \\
$x, y, z$ & 慣性軸位置ベクトル成分 $[\mathrm{m}]$ \\
$\alpha$ & 迎角 $[\mathrm{rad}]$ or $[\mathrm{deg}]$ \\
$\alpha_{0}$ & 零揚力迎角 $[\mathrm{rad}]$ or $[\mathrm{deg}]$ \\
$\beta$ & 横滑り角 $[\mathrm{rad}] \mathrm{or}[\mathrm{deg}]$ \\
$\rho$ & 空気密度 $\left[\mathrm{kg} / \mathrm{m}^{3}\right]$ \\
$\phi, \theta, \psi$ & オイラー角 $[\mathrm{rad}]$ or $[\mathrm{deg}]$ \\
{[]$_{C}$} & 追従機添字 \\
{[]$_{d}$} & 指令值添字 \\
{[]$_{\mathrm{LDR}}$} & 目標機添字 \\
{$\left[{ }^{*}\right]$} & 時間微分 \\
\hline
\end{tabular}

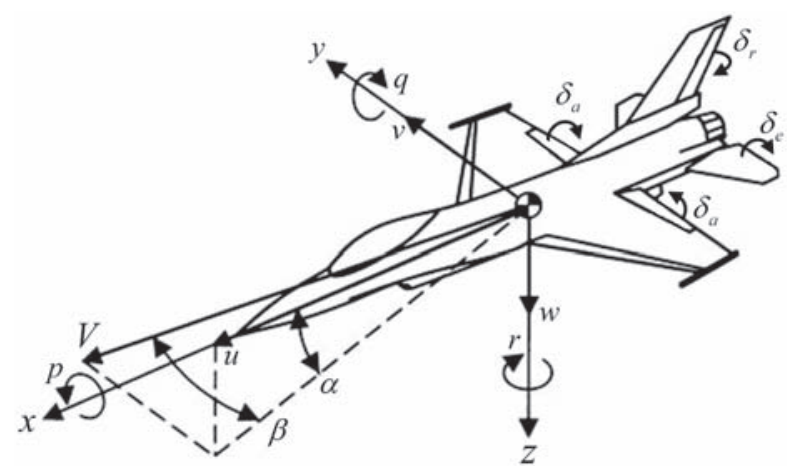

第 1 図 機体軸座標系の定義

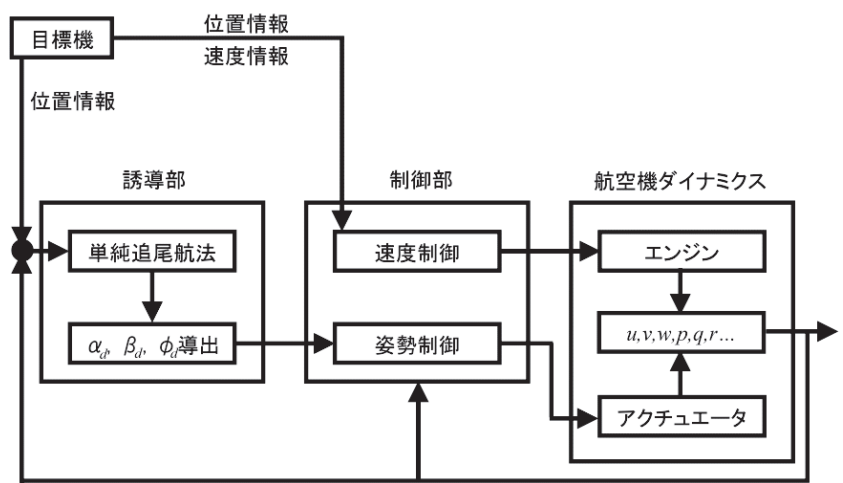

第 2 図 誘導制御系の概略図

従機が目標機の後方へ位置するという特徽を有している33). そこで，速度・距離を精密に制御する段階においては，誘 導・姿勢制御による目標機への指向はほぼ達成されており, 追従機は目標機の後方に位置していると仮定して, 速度距 離制御系を逆ダイナミクス法を用いて設計することを考え る, 通常, 速度は迎角と推力で調整されるが, 本システム では誘導力の発生に必要な迎角に応じて, 主に推力により 調整される，前述したように，逆ダイナミクス法を用いて

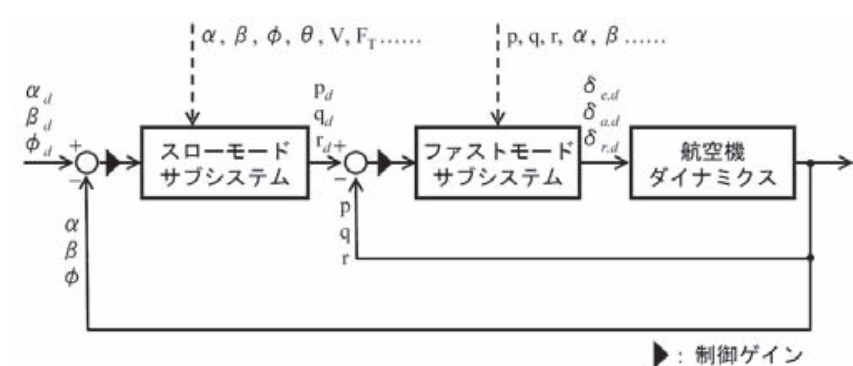

第 3 図 逆ダイナミクス法による姿勢制御の概略図

設計した迎角を含む姿勢制御系の応答は速度距離制御系よ り速く，迎角は速度に比べて速く目標值へ収束する。また， 迎角変化による速度制御への影響は逆システムにより推力 指令值に追加され補正される。

4.1 速度距離制御の定式化 本節では, 次節以降の基 本となる速度距離制御の定式化について示す2).

追従機が目標機との相対距離 $R$ で後方から目標機に追随 している状況を仮定する。速度 $V$ に関する運動方程式は, 次式で表される。

$$
\dot{V}=\dot{u} \cos \alpha \cos \beta+\dot{v} \sin \beta+\dot{w} \sin \alpha \cos \beta
$$

また，速度成分 $u, v, w$ を， $V, \alpha, \beta$ を用いて次のよう に表現することができる12)。

$$
\begin{aligned}
& u=V \cos \alpha \cos \beta, \quad v=V \sin \beta \\
& w=V \sin \alpha \cos \beta
\end{aligned}
$$

式 (4)に, 式 (1)〜 (3) および式 (5) を代入し整理すると, 次式を得る。

$$
\dot{V}=G-\frac{q_{t} S}{m} C_{D_{1}}+\frac{F_{T}}{m} \cos \alpha \cos \beta
$$

ここで

$$
\begin{aligned}
G=g & (-\sin \theta \cos \alpha \cos \beta+\cos \theta \sin \phi \sin \beta \\
+ & \cos \theta \cos \phi \sin \alpha \cos \beta) \\
C_{D_{1}}= & -\left(C_{x, t} \cos \alpha \cos \beta+C_{y, t} \sin \beta\right. \\
& \left.+C_{z, t} \sin \alpha \cos \beta\right)
\end{aligned}
$$

と置いた。式 (6) において, 逆ダイナミクス法に基づき, $\dot{V}$ を擬似入力 $U_{a}$ で置き換え， $F_{T}$ について解き，これを推 力指令值 $F_{T, d}$ とすると, 次式を得る.

$$
F_{T, d}=\left\{m U_{a}-m G+q_{t} S C_{D_{1}}\right\} /(\cos \alpha \cos \beta)
$$

以上のことから明らかなように，式 (9) を式 (6)の $F_{T}$ へ 代入すると，次式を得る。

$$
\dot{V}=U_{a}
$$

この $U_{a}$ の定式化について $4.2,4.3$ 節に示す. 


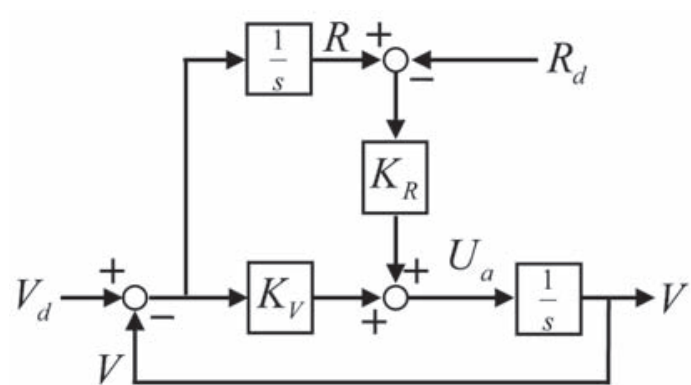

第 4 図＼cjkstart比例速度距離制御ブロック線図

4.2 比例制御による速度距離制御の定式化 追従機の 速度 $V$ を望ましい速度 $V_{d}$ に近づけるとともに, 相刘距離 $R$ が，維持したい相対距離 $R_{d}$ になるような制御系を構成 するため, 式 (10) に基づき，第 4 図に示すような比例制御 を考える，第 4 図より， $U_{a}$ は次式となる。

$$
U_{a}=K_{R}\left(R-R_{d}\right)+K_{V}\left(V_{d}-V\right)
$$

ここで， $K_{V}, K_{R}$ は制御ゲインである。これらのゲイン 決定法については, 航空機の長周期モードの周期を基準と する方法とエンジンの動特性を考慮した方法の 2 つを考案 し, 文献 2)に詳しく述べたので, ここでは結果のみを簡単 に示す.

\subsection{1 長周期モードの周期を基準としたゲイン決定法} 第 4 図より，ゲイン $K_{V}$ と $K_{R}$ を用いて速度距離制御系の 2 次システムが構成され， $K_{V}$ と $K_{R}$ はそれぞれ特性方程 式の 1 次係数と定数項に相当する. そこで，これを一般的な 2 次系の減衰係数 $\zeta_{v}$ と自然角周波数 $\omega_{n, v}$ に当てはめ, 係 数比較によりゲインを決定することを考える2). すなわち，

$$
s^{2}+K_{V} s+K_{R}=s^{2}+2 \zeta_{v} \omega_{n, v} s+\omega_{n, v}^{2}
$$

である。したがって，ゲイン $K_{V}$ と $K_{R}$ を求めるためには, 速度制御系の減衰係数 $\zeta_{v}$ と自然角周波数 $\omega_{n, v}$ を, 航空機 の特性に応じて定めれば良いことになる。航空機には一般 的に大きな制動力がないため, 減速は推力を小さくし空気 抵抗による他ないが，少なくとも長周期程度の速度変化は 期待できる，そこで， $V$ の $V_{d}$ に対する望ましい応答を得 るための 1 つの基準として, 速度距離制御において長周期 モードの周期 $\omega_{n, l p}$ を基準とすることを考え, $\omega_{n, v}=\omega_{n, l p}$ とし，また，応答が極力振動しないようにするため，減衰 係数 $\zeta_{v}$ は 1 に設定することとした. 以上より, 制御ゲイン は長周期近似の自然角周波数 $\omega_{n, l p}$ を用いて式 (13), (14) のように得られる。

$$
\begin{aligned}
& K_{R}=\omega_{n, v}^{2}=\omega_{n}^{2}=\left(\frac{\sqrt{2} g}{V}\right)^{2} \\
& K_{V}=2 \zeta_{v} \omega_{n, v}=2 \omega_{n}=\frac{2 \sqrt{2} g}{V}
\end{aligned}
$$

4.2.2 エンジンの動特性を考慮したゲイン決定法 4.2 .1 項の方法では追従機のエンジンの動特性を全く考慮してい ないが，エンジンの遅れが大きい場合には，その動特性は

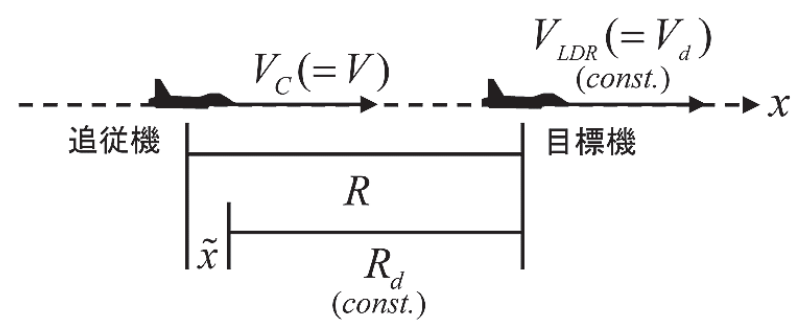

第 5 図 目標機と追従機の位置関係等の仮定

速度距離制御に大きな影響を及ぼす。そこで，エンジンの 動特性も考慮して制御ゲイン $K_{V}, K_{R}$ を決定する方法に ついて考えた ${ }^{2)}$. 追従機は第 5 図のように， $x$ 方向の小さ な相対距離誤差と速度誤差で, 一定速度で水平直線上を飛 行する目標機に追随していると仮定する。この仮定を用い, 航空機の運動方程式を簡略化した後，エンジンの動特性を 考慮するため, その動特性を時定数 $\tau_{E}$ の一次遅れとして 近似し，これを用いて式を整理すると，最終的に距離の応 答について 3 次の特性方程式を得る。ここで, 特性方程式 を考えたとき，その根の実部の最大值が最小となるよう，す なわち安定側に各ゲインを選んでいくと，すべての根が実 軸上で一致することから，特性根が 3 重実根となる場合を 考えると，次を得る。

$$
\begin{aligned}
& K_{V}=\frac{\left(1-\tau_{E} X_{u}\right)^{2}}{3 \tau_{E}} \\
& K_{R}=\frac{\left(1-\tau_{E} X_{u}\right)^{3}}{27 \tau_{E}^{2}}
\end{aligned}
$$

ここで $X_{u}$ は有次元安定微係数で, 次式で定義した

$$
X_{u}=-\frac{\rho S C_{D_{1}} V_{d}}{m}
$$

このとき，特性方程式は 3 重根となり，その根は,

$$
s=-\frac{\left(1-\tau_{E} X_{u}\right)}{3 \tau_{E}}
$$

である。一般に $X_{u}$ は負であるので, 式 (18) は常に負の 実根となる。

4.3 比例積分制御による速度距離制御の定式化 文献 2) にも述べたが， 4.2 節の方法では，空力係数に誤差があった 場合に距離に関して定常偏差を生じる。また, 目標機が定 加速度運動や定常旋回飛行をする場合などでも，同様の問 題を生じる. 例えば第 6 図は, 後に示すシミュレーション条 件に扔いて，4.2.2 項に示した方法で速度距離制御した場合 の相対距離の時間履歴である. 図中の凡例は, “ $\times 0.8 ”$ が空 力誤差 $-20 \%$ の場合, “ $\times 1.2$ ” が空力誤差 $+20 \%$ の場合, “without error” が空力誤差のない場合, “desired” は目標 值である。目標機は第 7 図に示すような，半径約 $3000[\mathrm{~m}]$ の水平定常旋回軌道をとって㧍り, 荷重倍数が約 $1.3 \mathrm{G}$ の 緩旋回である，第 6 図に見られるように，空力誤差がなく ても相対距離に数十メートルの定常偏差を生じ, 空力誤差 によって，さらに定常偏差が大きくなる，そこで，これを 解消するため, 第 8 図に示すような，距離に関する積分器 


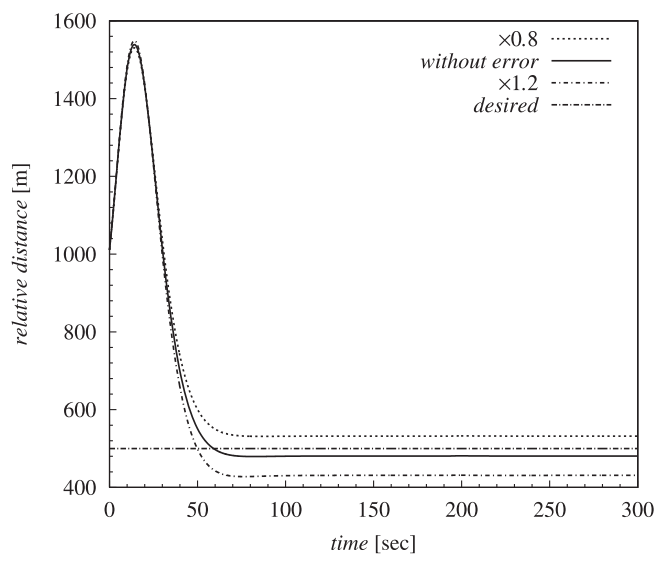

第 6 図 相対距離の時間履歴（定常偏差例）

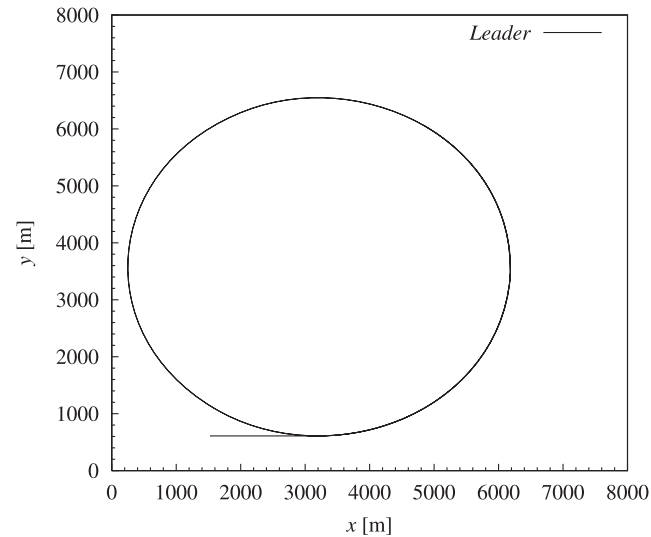

第 7 図 目標機の軌道

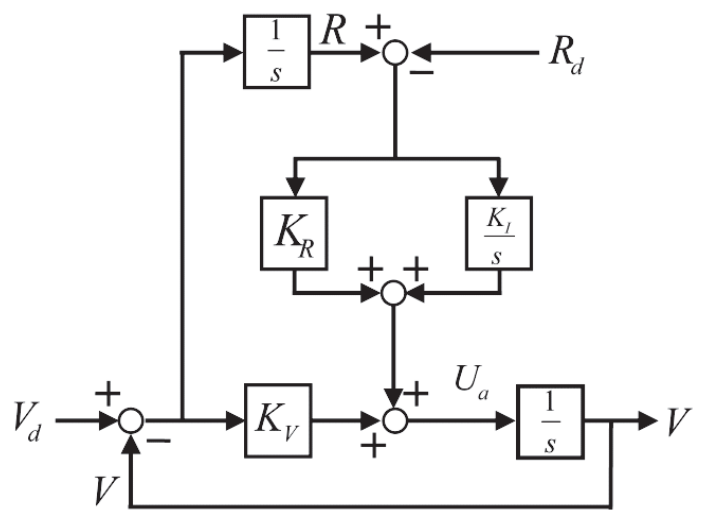

第 8 図＼cjkstart比例積分速度距離制御ブロック線図

を付加した比例積分制御を考える，第 8 図より， $U_{a}$ は次 式となる。

$$
U_{a}=K_{V} \tilde{v}+K_{R} \tilde{x}+K_{I} \int \tilde{x} \mathrm{~d} t
$$

ここで, $K_{V}, K_{R}, K_{I}$ は制御ゲインであり, $\tilde{v}, \tilde{x}$ は次式 で定義する。

$$
\tilde{v}=V_{d}-V
$$

$$
\tilde{x}=R-R_{d}
$$

次に, 制御ゲイン $K_{V}, K_{R}, K_{I}$ の決定法について, エ ンジンのダイナミクスを考慮しない場合とする場合の 2 つ の方法を述べる。

4.3.1 エンジンのダイナミクスを考慮しない場合のゲイ ン決定法 第 8 図において, 速度に関する伝達関数と距離 に関する伝達関数を求めることができるが, 距離について 考えることによって制御ゲインを定める。 そこで, $V_{d}=0$ として $R_{d}$ から $R$ への伝達関数を求めると, 次式を得る.

$$
\frac{R}{R_{d}}=\frac{K_{R} s+K_{I}}{s^{3}+K_{V} s^{2}+K_{R} s+K_{I}}
$$

式 $(22)$ より，系の特性方程式は次式となる。

$$
f(s)=s^{3}+K_{V} s^{2}+K_{R} s+K_{I}=0
$$

式 (23) が系の初期值に対する応答特性を決める。ここで, 特性方程式を考えたとき, その根の実部の最大值が最小と なるよう，すなわち安定側に各ゲインを選んでいくと，す べての根が実軸上で一致することから，特性根が 3 重実根 となる場合を考える。 3 次方程式 (23) が 3 重実根を持つ場 合，明らかに

$$
f(s)=f^{\prime}(s)=f^{\prime \prime}(s)=0
$$

である。したがって，次の連立方程式を満たせばよい。

$$
\begin{aligned}
& s^{3}+K_{V} s^{2}+K_{R} s+K_{I}=0 \\
& 3 s^{2}+2 K_{V} s+K_{R}=0 \\
& 6 s+2 K_{V}=0
\end{aligned}
$$

以上より，3 重根を仮定した根と係数の関係を用い，次を 得る。

$$
\begin{array}{r}
K_{R}=\frac{K_{V}^{2}}{3} \\
K_{I}=\frac{K_{V}^{3}}{27} \\
\text { このとき, 根は } \\
s=-\frac{K_{V}}{3}
\end{array}
$$

である.ここで, 制御ゲイン $K_{R}, K_{I}$ は， $K_{V}$ の関数とし て表されている. 未知数は $K_{V}, K_{R}, K_{I}$ の 3 つであるの に対し式は 2 本しかなく，一意には定まらない。 また，フ ルビッツの安定判別法を用いると

$$
K_{V}>0, \quad K_{R}>\frac{K_{I}}{K_{V}}, \quad K_{I}>0
$$

の安定条件を得るが，これによると $K_{V}$ は正であれば安定 であるので, 式 $(31)$ の安定条件だけでは $K_{V}$ の上限を決 めることはできない. そこで次に, 式 $(22)$ の分子も含めて 考えることによって $K_{V}$ の決定法を示す. 前述の議論から 明らかなように, 式 $(22)$ の極は 3 つとも式 (30)で, 零点 


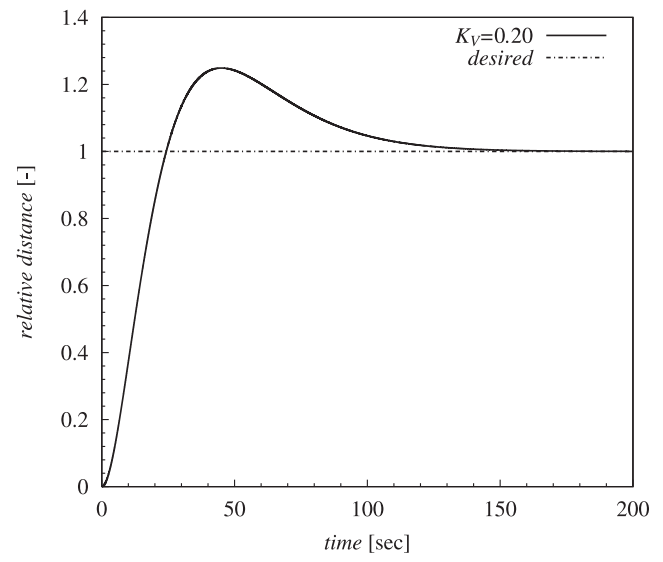

第 9 図 相対距離の時間応答の例

は $-K_{V} / 9$ で与えられるので, 極零配置から $K_{V}$ を決め ることもできるが，本論文ではステップ入力に対する応答 波形から $K_{V}$ を決めることにする。この系にステップ入力 を加えたときの応答は, 式 (22) に式 (28), (29) の関係を 用い, $R_{d}=1 / s$ として整理すると，

$$
R(s)=\frac{1}{s}-\frac{s^{2}+K_{V} s}{\left(s+\frac{K_{V}}{3}\right)^{3}}
$$

と表される. 式 (32) を部分分数に展開すると, 次式を得る.

$$
\begin{aligned}
R(s)= & \frac{1}{s}-\frac{1}{s+\frac{K_{V}}{3}}-\frac{K_{V}}{3} \frac{1}{\left(s+\frac{K_{V}}{3}\right)^{2}} \\
& +\frac{K_{V}^{2}}{9} \frac{2}{\left(s+\frac{K_{V}}{3}\right)^{3}}
\end{aligned}
$$

式 (33) をラプラス逆変換して時間応答を求めると, 次式を 得る.

$$
R(t)=1+e^{-\frac{K_{V}}{3} t}\left(\frac{K_{V}^{2}}{9} t^{2}-\frac{K_{V}}{3} t-1\right)
$$

式 (22) において, 特性根は 3 重実根となるように制御ゲイ ンを調整しても零点が存在するので，ステップ応答はオー バーシュートして最終值に整定する形となる，例えば，飛行 速度を $154[\mathrm{~m} / \mathrm{s}]$ として式 $(14)$ に代入して得た $K_{V} \approx 0.2$ を式 $(34)$ に用いて時間応答を描くと第 9 図のようになる。 この図は $R(t)$ の典型的な形状を示している.

はじめにピーク值を求めるために, ピーク時間 $T_{p}$ を求 める。第 9 図よりピーク時間 $T_{p}$ は,

$$
\frac{\mathrm{d}}{\mathrm{d} t} R(t)=0
$$

を満たす $t$ である. 式 $(34)$ を時間微分すると, 次式を得る.

$$
\frac{\mathrm{d}}{\mathrm{d} t} R(t)=e^{-\frac{K_{V}}{3} t}\left(-\frac{K_{V}^{3}}{27} t^{2}+\frac{K_{V}^{2}}{3} t\right)
$$

式 $(36)$ が 0 となるのは, $t \neq \infty$ のとき $e^{-\frac{K_{V}}{3} t} \neq 0$ であ

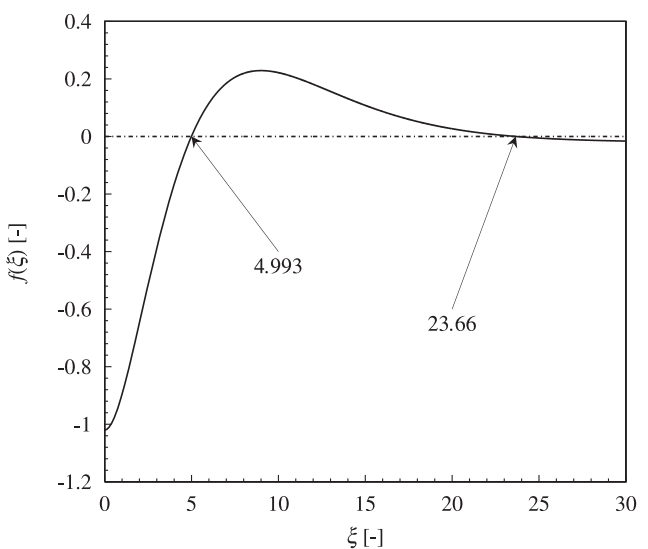

第10図 $f(\xi)$ の応答

るから，次式を満たす場合である．

$$
t\left(-\frac{K_{V}^{3}}{27} t+\frac{K_{V}^{2}}{3}\right)=0
$$

式 (37) を満たす $t($ ただし $t \neq 0)$ が $T_{p}$ であるから, 式 $(37)$ より次式を得る。

$$
T_{p}=\frac{9}{K_{V}}
$$

式 (38) を式 (34) に代入するとピーク值 $R_{\max }$ が得られる.

$$
R_{\max }=R\left(T_{p}\right)=1+5 e^{-3} \approx 1.2489
$$

式 (39) から明らかなようにピーク值は $K_{V}$ に関係なく一 定值となるので，ピーク值を指定して $K_{V}$ を決めることは できない，そこで，整定時間 $T_{s}$ を指定して $K_{V}$ を決める ことを考える. $T_{s}$ を $R(t)$ が目標值の $2 \%$ 以内に収束した ときの時間と定義すると, 式 $(34)$ より, 整定時間 $T_{s}$ は次 式を満たす。

$$
R\left(T_{s}\right)=1.02
$$

すなわち，

$$
e^{-\frac{K_{V}}{3} T_{s}}\left(\frac{K_{V}^{2}}{9} T_{s}^{2}-\frac{K_{V}}{3} T_{s}-1\right)-0.02=0
$$

ここで，式 (41) は $K_{V}$ と $T_{s}$ に関して対称となっている ことが分かる。そこで,

$$
\xi=K_{V} T_{s}
$$

とおくと, 式 (41) は次式と書ける.

$$
f(\xi)=e^{-\frac{\xi}{3}}\left(\frac{\xi^{2}}{9}-\frac{\xi}{3}-1\right)-0.02=0
$$

式 $(43)$ に示す $f(\xi)$ の応答は，第 10 図のようになる。第 10 図にも見られるとおり, 式 (43) を満たす $\xi$ は 2 個存 在するが, 大きい方が整定時間に相当する值であり, 次と なる。

$$
\xi \approx 23.66
$$


式 (42)，(44)より $T_{s}$ と $K_{V}$ は反比例の関係にあり， $K_{V}$ は $T_{s}$ の関数として次式で与えられる.

$$
K_{V} \approx \frac{23.66}{T_{s}}
$$

以上より, ゲイン決定のアルゴリズムを縓めると, 以下の ようになる。

＜提案するゲイン決定アルゴリズム>

1) $T_{s}$ を与える.

2) 式 (45)により $K_{V}$ を定める.

$3)$ 式 (28), (29) に $K_{V}$ を代入し, $K_{R}, K_{I}$ を得る. ここで $T_{s}$ の決定法について, 以下に一例を示す， $T_{s}$ は飛 行距離に関する整定時間なので，この決定には，速度距離 制御系以外の制御系との干渉や，航空機の減速特性を考慮 する必要がある。本研究に扔いて, 速度制御系の収束は, 姿 勢制御系, 誘導系よりも遅いものとして設計しているため, 姿勢制御系や誘導系と干涉しないよう，速度制御系のカッ トオフ周波数が, 姿勢制御系, 誘導系のそれよりも, 十分 に小さくなることが条件の 1 つとして考えられる。また, もう 1 つの条件として, 衝突を回避するため推力の飽和な く減速を実現できること，があげられる，前述のように航 空機には一般的に大きな制動力がないため, 減速は推力を 小さくし空気抵抗による他ないが，少なくとも長周期程度 の速度変化は期待できる。，そこで，4.2.1 項同様，長周期の 周期を基準とする方法を提案する。長周期は誘導系・姿勢 制御系に比べてはるかに遅いため, 前述の条件を満足して いる. 長周期モードの自然角周波数 $\omega_{n, l p}$ は, 次式で近似 される ${ }^{12)}$

$$
\omega_{n, l p} \approx \frac{\sqrt{2} g}{V_{0}} \approx \frac{\sqrt{2} g}{V_{d}}
$$

ここで, $V_{0}$ を目標速度 $V_{d}$ とした $\omega_{n, l p}$ を用いて，周期 $T_{l p}$ は次式で表される。

$$
T_{l p} \approx \frac{2 \pi}{\omega_{n, l p}}
$$

例えば，望ましい整定時間 $T_{s}$ を 3 周期分とすれば， $T_{s}$ は 次式となる。

$$
T_{s}=3 T_{l p}=3 \frac{2 \pi V_{d}}{\sqrt{2} g}=\frac{3 \pi \sqrt{2}}{g} V_{d}
$$

数值例として, 式 $(48)$ に扔ける $V_{d}$ を後のシミュレーショ ンに扮ける目標速度 $154[\mathrm{~m} / \mathrm{s}]$ とすると, $T_{s} \approx 210[\mathrm{sec}]$ となる。このとき, $K_{V} \approx 0.1127$ である.

4.3.2 エンジンのダイナミクスを考慮する場合のゲイン 決定法 第 5 図に示した位置関倸の仮定より,

$$
\alpha=\alpha_{0}, \quad \beta=0, \quad \phi=0, \quad \theta=\theta_{0}=\alpha_{0}
$$

である. 以上の仮定から, 追従機の速度の運動方程式は式

(6) を整理して次式で与えられる.

$$
m \dot{V}=-q_{t} S C_{D_{2}}+F_{T} \cos \alpha_{0}
$$

ここで

$$
C_{D_{2}}=-\left(C_{x, t} \cos \alpha_{0}+C_{z, t} \sin \alpha_{0}\right)
$$

である. 簡略化した追従機速度の運動方程式 (50) に, 動圧 $q_{t}=0.5 \rho V^{2}$, 式 (20) を代入して整理し, $\tilde{v}^{2}$ を 2 次の微 小量とみなして無視し, 線形化すると次式を得る.

$$
m \dot{V}=-S C_{D_{2}}\left(\frac{1}{2} \rho V_{d}^{2}-\rho V_{d} \tilde{v}\right)+F_{T} \cos \alpha_{0}
$$

逆ダイナミクス法に基づき, 式 (52) を推力 $F_{T}$ で解き, こ れを推力指令值 $F_{T, d}$ で置き換え, $\dot{V}$ を擬似入力 $U_{a}$ で置 き換えると，次式を得る。

$$
F_{T, d} \cos \alpha_{0}=m U_{a}+S C_{D_{2}}\left(\frac{1}{2} \rho V_{d}^{2}-\rho V_{d} \tilde{v}\right)
$$

式 (53)の $U_{a}$ に式 (19) を代入し, 式 (20), (21) の仮定 より, 次式

$$
\tilde{v}=\dot{\tilde{x}}
$$

を用いて整理すると, 次を得る。

$$
\begin{aligned}
\frac{F_{T, d}}{m} \cos \alpha_{0}= & K_{V} \dot{\tilde{x}}+K_{R} \tilde{x}+K_{I} \int \tilde{x} \mathrm{~d} t \\
& +X_{u} \dot{\tilde{x}}-\frac{1}{2} X_{u} V_{d}
\end{aligned}
$$

ここで, 有次元安定微係数 $X_{u}$ は, 式 (17) である. 式 (55) を, $\tilde{x}(0)=0$ の条件のもとラプラス変換すると, 次式を 得る.

$$
\begin{aligned}
& \frac{F_{T, d}(s)}{m} \cos \alpha_{0} \\
& =\left\{\left(K_{V}+X_{u}\right) s+K_{R}+\frac{K_{I}}{s}\right\} \tilde{X} \\
& \quad-\frac{1}{2} X_{u} V_{d} \frac{1}{s}
\end{aligned}
$$

推力 $F_{T}$ と, その指令值 $F_{T, d}$ の間のダイナミクスを時定 数 $\tau_{E}$ の一次遅れで近似できると仮定し, 式 (57) で定義 する.

$$
\frac{F_{T}(s)}{F_{T, d}(s)}=G_{E}=\frac{1}{1+\tau_{E} s}
$$

式 (56)に式 (57) を代入すると，次式となる.

$$
\begin{aligned}
& \frac{F_{T}(s)}{m} \cos \alpha_{0} \\
& =G_{E}\left\{\left(K_{V}+X_{u}\right) s+K_{R}+\frac{K_{I}}{s}\right\} \tilde{X} \\
& \quad-\frac{1}{2} X_{u} V_{d} G_{E} \frac{1}{s}
\end{aligned}
$$

ところで, 航空機の速度の運動方程式 (52) に, 式 (20), (21) の仮定より, 次式

$$
\dot{V}=-\dot{\tilde{v}}
$$


を代入し整理すると，式 (17) も用いて次を得る.

$$
\ddot{\tilde{x}}-X_{u} \dot{\tilde{x}}=-\frac{F_{T}}{m} \cos \alpha_{0}-\frac{1}{2} X_{u} V_{d}
$$

式 $(60)$ を, $\dot{\tilde{x}}(0)=\tilde{x}(0)=0$ の条件のもとラプラス変換す ると, 次式を得る。

$$
\left(s^{2}-X_{u} s\right) \tilde{X}=-\frac{F_{T}(s)}{m} \cos \alpha_{0}-\frac{1}{2} X_{u} V_{d} \frac{1}{s}
$$

式 $(61)$ に式 $(58)$ を代入し, $F_{T}(s)$ を消去して整理すると, 位置誤差に関して次式を得る。

$$
\left(\tau_{E} s^{4}+X_{\tau} s^{3}+K_{V} s^{2}+K_{R} s+K_{I}\right) \tilde{X}=0
$$

ここで,

$$
X_{\tau}=1-\tau_{E} X_{u}
$$

と置いた，式 (62) から，この系の応答の特性は，次式によ り決まる。

$$
\tau_{E} s^{4}+X_{\tau} s^{3}+K_{V} s^{2}+K_{R} s+K_{I}=0
$$

ここで, 特性方程式 (64) の根の実部の最大值が最小となる よう，すなわち安定側に各ゲインを選んでいくと，すべて の根が実軸上で一致することから, 特性根が 4 重実根とな る場合を考える。 4 重実根を持つ 4 次方程式は, その解を $\gamma_{e q}$ とすると,

$$
\left(s-\gamma_{e q}\right)^{4}=0
$$

と表される。これを展開すると，次を得る．

$$
s^{4}-4 \gamma_{e q} s^{3}+6 \gamma_{e q}^{2} s^{2}-4 \gamma_{e q}^{3} s+\gamma_{e q}^{4}=0
$$

そこで，4 重実根を仮定し， $K_{V} ， K_{R}, K_{I}$ を決定するた め, 式 (65) を展開した式 (66) と, 式 (64) を係数比較する と, 式 $(67) \sim(69)$ の関係を得る.

$$
\begin{aligned}
& K_{V}=6 \tau_{E} \gamma_{e q}^{2} \\
& K_{R}=-4 \tau_{E} \gamma_{e q}^{3} \\
& K_{I}=\tau_{E} \gamma_{e q}^{4}
\end{aligned}
$$

このとき, 根は

$$
\gamma_{e q}=-\frac{X_{\tau}}{4 \tau_{E}}=-\frac{1-\tau_{E} X_{u}}{4 \tau_{E}}
$$

である。一般に $X_{u}$ は負であるので，式 (70) は常に負の 実根となる。式 (67)〜 (69) は, 式 (70) を代入すると， $\tau_{E}$ と $X_{u}$ の式となる。例えば, 高度 $2438[\mathrm{~m}](8000[\mathrm{ft}])$, 速 度 $154[\mathrm{~m} / \mathrm{s}](300[\mathrm{kt}])$ の定常飛行を仮定して $X_{u}$ を求め, $\tau_{E}=3.0[\mathrm{sec}]$ とすると， $K_{V}=0.1261$ となる.これは, 式 (41) を用いて整定時間を求めると, $T_{s}=187.7[\mathrm{sec}]$ に 相当する. 以上より, 式 (67)〜 (69) により, 制御ゲイン $K_{V}, K_{R}, K_{I}$ を得ることができる.

$$
\text { 5. シミュレーション }
$$

以下に，本論文で述べた理論を無人機とみなした YF$16{ }^{13)}$ に適用し，シミュレーションを行った結果を述べる が，便宜上，本論文で提示した制御系について，次のよう に呼称するものとする。

$C_{V}-11: 4.2 .1$ 節に示した，積分器を含まずエンジンの動 特性を考慮しない方法

$C_{V}-12: 4.2 .2$ 節に示した, 積分器を含まずエンジンの動 特性を考慮する方法

$C_{V}-21: 4.3 .1$ 節に示した, 積分器を導入しエンジンの動 特性を考慮しない方法

$C_{V}-22: 4.3 .2$ 節に示した, 積分器を導入しエンジンの動 特性を考慮する方法

目標機の軌道は，第 7 図に示すような水平面内の定常旋回 軌道であり，高度変化はほとんどない，目標機はシミュレー ション開始時から 10 秒間, 等速直線飛行を行った後, 水平 定常旋回に入り，300 秒のシミュレーション時間が終了す るまで同旋回を維持する。目標機の軌道は水平面内のもの であるが，追従機は 6 自由度の剛体モデルで，エンジンの 時定数 $\tau_{E}$ は 3.0 で一定とし, 制御ゲイン決定のために用

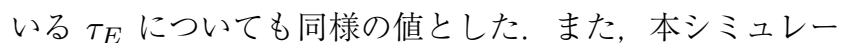
ションでは，以下を仮定した。

1) 追従機の質量は一定とする.

2) エンジンの回転トルクおよびジャイロ効果は無視する.

3）目標機の位置情報，速度情報，および追従機の状態量 は既知とし，遅れや誤差なく追従機の誘導制御系に使 用できるものとする。

4) 大気擾乱，突風等は無視できるほど小さいとする。 シミュレーション開始時の初期設定は，第 2 表のと抢りであ り, 初期位置については, 前後方向 $(x)$, 左右方向 $(y)$, 上 下方向 $(h)$ にそれぞれ変位を持たせ，初期速度については 目標機の方が追従機よりも速い設定とした，以下にシミュ レーション結果を述べるが，4.2 節に示した積分器を含ま ない速度距離制御 $\left(C_{V^{-}}-11, C_{V^{-}}-12\right)$ を適用した場合の結 果については文献 2) に詳しく述べたので，4.3 節に示した 比例積分制御を用いた速度距離制御 $\left(C_{V}-21, C_{V}-22\right)$ を 適用した場合について述べる。

ところで，本ケースのように初期相対距離が大きく目標 相対距離から離れている場合，シミュレーション開始当初 から $C_{V^{-}}-21, C_{V^{-}}-22$ の速度距離制御を適用することには問 題がある。実際，前論文で示した制御系に積分器を付加し たのは定常偏差を除くためであるが，応答の即応性という 観点から言えば，前論文の方法が優れている，それ故，制 御開始当初は前論文の方法を用い，相対距離や速度がほぼ

\begin{tabular}{cccc}
\multicolumn{2}{c}{ 第 2 表 シミュレーションの初期設定 } \\
\hline & 追従機 & \multicolumn{3}{c}{ 目標機 } \\
\hline$x_{C}$ & $610[\mathrm{~m}]$ & $x_{\mathrm{LDR}}$ & $1524[\mathrm{~m}]$ \\
$y_{C}$ & $305[\mathrm{~m}]$ & $y_{\mathrm{LDR}}$ & $610[\mathrm{~m}]$ \\
$h_{C}$ & $2134[\mathrm{~m}]$ & $h_{\mathrm{LDR}}$ & $2438[\mathrm{~m}]$ \\
$V_{C}$ & $103[\mathrm{~m} / \mathrm{s}]$ & $V_{\mathrm{LDR}}$ & $154[\mathrm{~m} / \mathrm{s}]$ \\
\hline
\end{tabular}




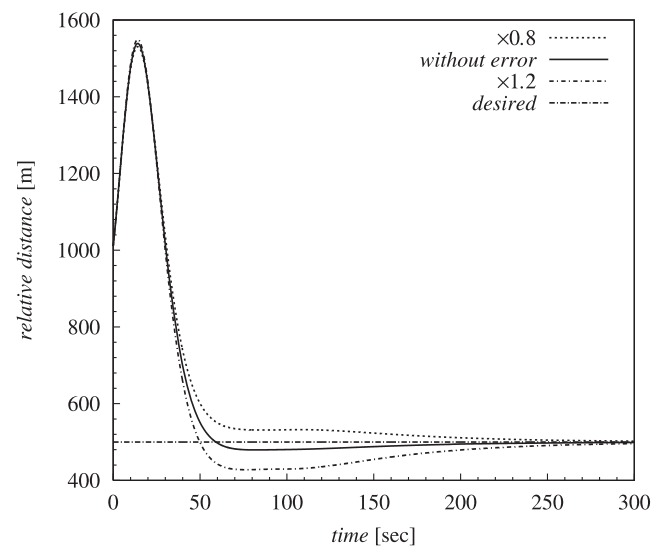

第 11 図 相対距離の時間履歴 $\left(C_{V^{-}}-21\right)$

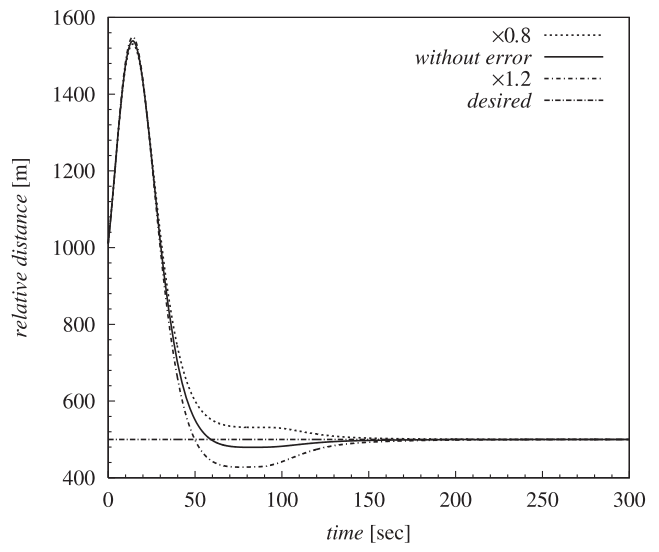

第 12 図 相対距離の時間履歴 $\left(C_{V}-22\right)$

目標值に近づいたなら本論文で述べた方法を用いるように すべきである，以上のことを考慮して，シミュレーション 開始当初は $C_{V}-12$ の速度距離制御を適用し, 相対距離と速 度の変化が, 2 秒間, それぞれ任意に設定した微小量以内に 整定したならば，速度距離制御系を $C_{V}-21$ または $C_{V}-22$ へ切り換えるものとした，各ゲインは，本論文で述べたゲ イン決定法により，次で与えた。

$<C_{V}-21>\left(V_{d}=154[\mathrm{~m} / \mathrm{s}], \quad T_{s}=210[\mathrm{sec}]\right)$

$$
\begin{aligned}
& K_{V}=1.127 \times 10^{-1} \\
& K_{R}=4.231 \times 10^{-3} \\
& K_{I}=5.297 \times 10^{-5}
\end{aligned}
$$

$<C_{V}-22>\left(\tau_{E}=3.0[\mathrm{sec}], \quad X_{u}=-0.01408\right)$

$$
\begin{aligned}
& K_{V}=1.261 \times 10^{-1} \\
& K_{R}=7.033 \times 10^{-3} \\
& K_{I}=14.71 \times 10^{-5}
\end{aligned}
$$

第 11，12 図は，それぞれ，相対距離と速度の変化が整定 した後, 速度距離制御系を $C_{V}-21, C_{V}-22$ へ切り換えた場 合の，相対距離の時間履歴である。図中の凡例は, 既出の 第 6 図と同様である。第 13,14 図は，それぞれ，空力誤差 がないケースにおいて， $C_{V}-21, C_{V}-22$ を適用した場合の

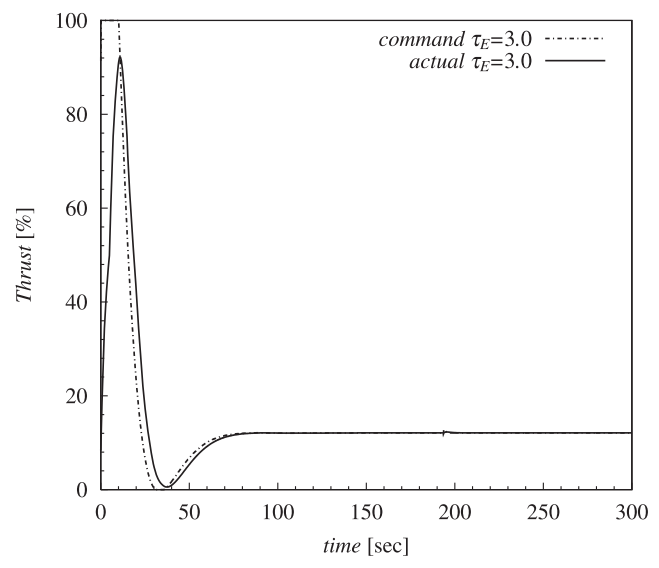

第 13 図 推力の時間履歴 $\left(C_{V}-21\right)$

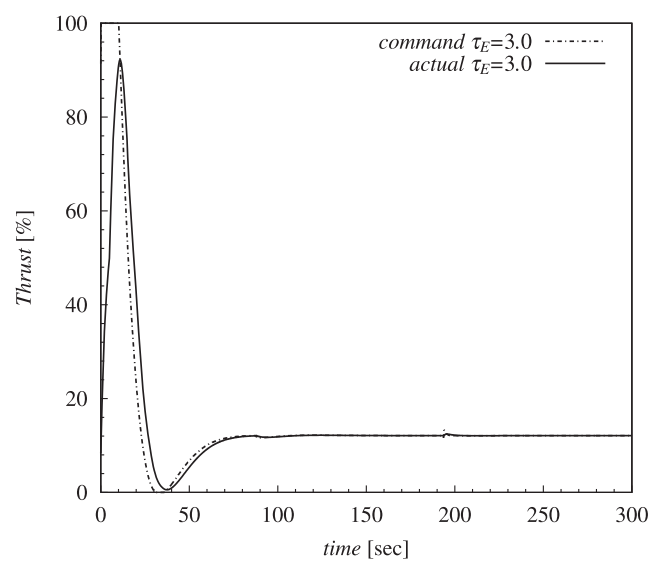

第 14 図 推力の時間履歴 $\left(C_{V}-22\right)$

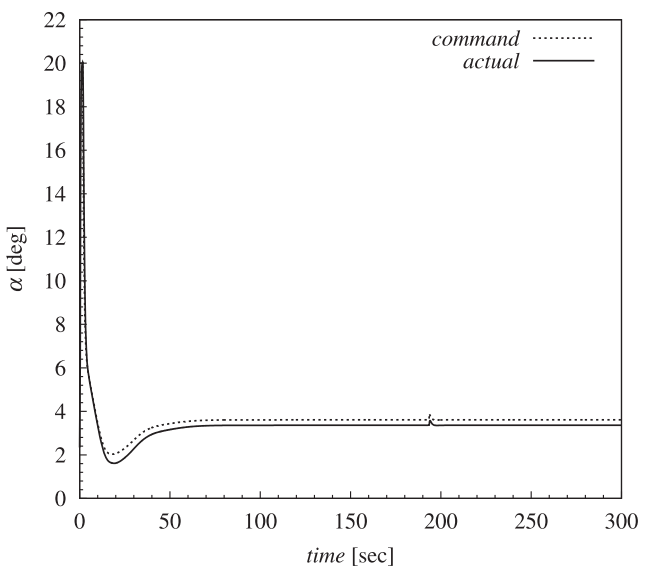

第 15 図 空力誤差がない場合の迎角時間履歴 $\left(C_{V}-21\right)$

推力の時間履歴であり, 第 11,12 図の “without error” に 対応する，紙面の都合で掲載は割愛するが， $\pm 20 \%$ の空力 誤差があるケースについても, 推力の時間履歴は同様の傾 向を示した。なお，第 11,12 図のいずれのケースにおいて も，初期の段階で相対距離が大きくなっている。これは，追 従機が目標機に指向するために姿勢を急激に変化させたた め，誘導抵抗の増大により速度が低下した結果である。一 例として, $C_{V}-21$ で空力誤差がない場合の迎角時間履歴を 
あげると，第 15 図のようになっている。 シミュレーション 開始当初, 大きな迎角をとっているのは, 前述のと抢り, 追 従機を目標機の方向へ向けるためであり, 空力誤差がある 場合についても同様の傾向が見られた，これにより，追従 機は直ちに姿勢制御を行って目標機に指向する。このため, その後は第 5 図に示される仮定にほぼ近い状態で速度距離 制御が行われており, 速度距離制御系の違いによる影響は, その後に顕著に現れる。したがって, 本論文では速度距離 制御に関するパラメータに重点を置き, 姿勢に関する時歴 については紙面の都合上，割愛する，推力に関しては，第 13，14図に見られるように，その実効值は目標值によく追 随して抢り，また，制御系の切り替えによる振動もほとん ど発生していない，一方，相対距離に関しては，第 $11 ， 12$ 図から明らかなように, どちらのケースに拉いても第 6 図 で生じていた定常偏差が解消され，目標值に収束している。 また, エンジンの動特性を考慮していない $C_{V}-21$ を用いた 場合（第 11 図）では，収束に 300 秒程度を要しているの に対し，エンジンの動特性を考慮した $C_{V}-22$ を用いた場合 (第 12 図) に扔いては，160 秒程度で収束しており, 前者 より後者の方が，より速く収束していることが分かる。こ の収束時間の差については， $C_{V}-21 ， C_{V}-22$ のそれぞれの 方法で得られるゲイン $K_{V}$ の違いも影響している. $C_{V}-21$ に打ける $K_{V}$ を， $C_{V}-22$ で得た $K_{V}$ と同じ值にすると, 第 16 図のようになる。第 16 図では，収束にかかる時間は 約 250 秒程度であり, 両者の収束時間の差は小さくなった が，エンジンの動特性を考慮した $C_{V}-22$ を用いた方が収束 時間が短いという傾向に変化はなかった。このように，同 じゲイン $K_{V}$ を用いた場合には， $C_{V}-22$ の方が収束が速 く，また， $C_{V}-22$ ではゲインが一意に定まるので，設計が 容易である。しかし，逆に言えば，ゲインの決定に関して 自由度がない，他方， $C_{V}-21$ ではゲイン $K_{V}$ は設計者が整 定時間 $T_{s}$ を任意に定めることができるので， $K_{V}$ を適切 に，より大きくすることで収束時間を短くすることができ る. 例えば, $C_{V}-21$ に扔いて $K_{V}=0.16\left(T_{s} \approx 150\right.$ [sec] 相当）とすると， $C_{V}-22$ を用いた場合と，ほぼ同等の収束 時間となる．また， $K_{V}$ をより大きくすることによって，よ り速く収束する結果も得られた。しかしながら， $K_{V}$ を過 度に大きくとると, 制御入力である推力が制御系の切り替 え時に振動する傾向が見られるようになる。ささらに $K_{V}$ を 大きくとると，推力の飽和状態が長くなり，その期間中は 完全な逆システムが構成されていないので制御性能の悪化 を招き, このため相対距離の応答が振動的となり, 収束時 間は逆に長くなるという結果を得た。このように， $C_{V}-21$ ではゲイン $K_{V}$ を設計者が任意に定めることができ, 制御 性能をある程度自由に変えることができるが, 最も収束時 間の短くなるような $K_{V}$ の值は, 飛行状態や目標速度, 工 ンジンの応答性能等によって変化するため, これを選定す るのは容易ではない. このため, 4.3.1 項に示したように, 長周期モードの周期を基準として許容できる整定時間を定 め， $K_{V}$ を決定する方法等が有用である. 本ケースの場合, 長周期の 2 周期分に相当する程度の整定時間とするのが限

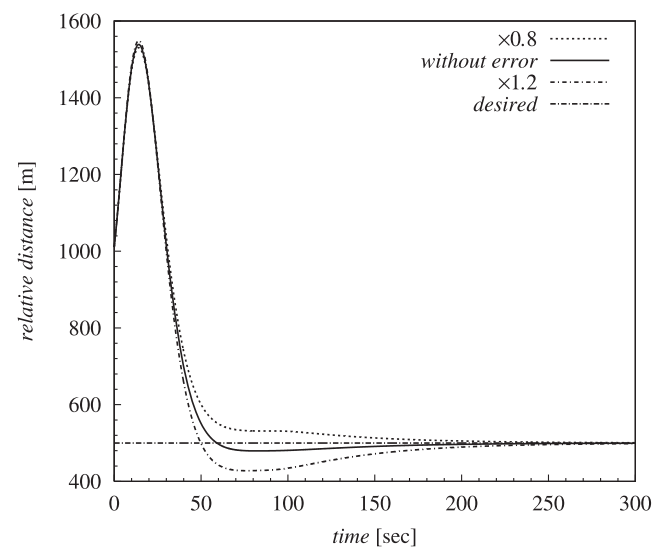

第 16 図 相対距離の時間履歴 $\left(C_{V^{-}}-22\right.$ の $K_{V}$ を用いた $\left.C_{V}-21\right)$

界であり，それ以上に短い整定時間から $K_{V}$ を定めた場合， 上述したような制御性能の悪化が見られた。

以上より， $C_{V}-21 ， C_{V}-22$ のどちらを用いても, 目的で ある定常偏差の解消は実現することができた。ただし，前 述したように提案した積分器を導入する方法は, 追随の最 終段階において効果を発揮すべきものであり，相対距離が 目標值から大きく離れている初期の段階からの適用は好ま しくない。これは, 積分項が過大となると, 収束までに大 きなオーバーシュートを伴うからである。追随飛行時の距 離制御において，オーバーシュートは衝突の危険があるこ とを意味している。航空機間の速度・距離を制御する場合, 飛行中に逆推力を用いることはできず, 特に減速側の応答 は空気抵抗によるもので遅い.したがって, 衝突回避のた めには大きなオーバーシュートの発生は避けるべきである. また，相対距離が目標值から大きく離れている場合，入力 （推力）が飽和する可能性がある. 入力の飽和が起きると, 所望の性能が得られなくなるため, 制御性能の悪化を招く 結果となる。 これらの点で, 相対距離が目標值から大きく 離れている初期の段階からの適用は好ましくない。本論文 で提案した $C_{V}-21$ や $C_{V}-22$ が効果を発揮すべき状況は, 最終的な偏差を解消したい場合, すなわち追随の最終段階 であって，相対距離や相対速度が一定以下に整定するまで の間は， $C_{V}-11$ または $C_{V}-12$ による制御で十分な追随性を 確保できる2)。したがって，本節で示したように，追随の初 期段階では $C_{V}-11$ または $C_{V}-12$ を用い, 速度と相対距離 が整定した追随の最終段階において, 制御系を $C_{V}-21$ また は $C_{V^{-}} 22$ に切り換えて適用するのが良い. $C_{V^{-}} 21, C_{V^{-}}-22$ のどちらが適しているかは状況にもよるが，例えば，空中 給油等, 目標機の機動がほとんどないようなケースでは, $C_{V}-22$ を用いた方が設計も容易であり, 速い収束が期待で きる. 他方, 大きな機動をとる目標機に追随する場合や, 収 束時間を速くする必要がない場合には, ゲイン決定の自由 度がある $C_{V}-21$ を用い, 整定時間が比較的長くなるよう に設計すれば, 制御入力である推力飽和の可能性を少なく することができるので, 制御性能の悪化を軽減できる.

加えて, 初期相対距離が, より大きい場合, より小さい 場合でのシミュレーション結果について紹介する。初期相 


\begin{tabular}{|c|c|c|c|}
\hline \multicolumn{2}{|r|}{ 追従機 } & \multicolumn{2}{|c|}{ 目標機 } \\
\hline$x_{C}$ & $610[\mathrm{~m}]$ & $x_{\mathrm{LDR}}$ & $2438[\mathrm{~m}]$ \\
\hline$y_{C}$ & $305[\mathrm{~m}]$ & $y_{\mathrm{LDR}}$ & $\underline{1219}[\mathrm{~m}]$ \\
\hline$h_{C}$ & $2134[\mathrm{~m}]$ & $h_{\mathrm{LDR}}$ & $2438[\mathrm{~m}]$ \\
\hline$V_{C}$ & $103[\mathrm{~m} / \mathrm{s}]$ & $V_{\mathrm{LDR}}$ & $154[\mathrm{~m} / \mathrm{s}]$ \\
\hline
\end{tabular}

第 4 表 シミュレーションの初期設定（小）

\begin{tabular}{cccc}
\hline & 追従機 & \multicolumn{2}{c}{ 目標機 } \\
\hline$x_{C}$ & $610[\mathrm{~m}]$ & $x_{\mathrm{LDR}}$ & $\underline{762}[\mathrm{~m}]$ \\
$y_{C}$ & $305[\mathrm{~m}]$ & $y_{\mathrm{LDR}}$ & $\underline{457}[\mathrm{~m}]$ \\
$h_{C}$ & $2134[\mathrm{~m}]$ & $h_{\mathrm{LDR}}$ & $2438[\mathrm{~m}]$ \\
$V_{C}$ & $103[\mathrm{~m} / \mathrm{s}]$ & $V_{\mathrm{LDR}}$ & $154[\mathrm{~m} / \mathrm{s}]$ \\
\hline
\end{tabular}

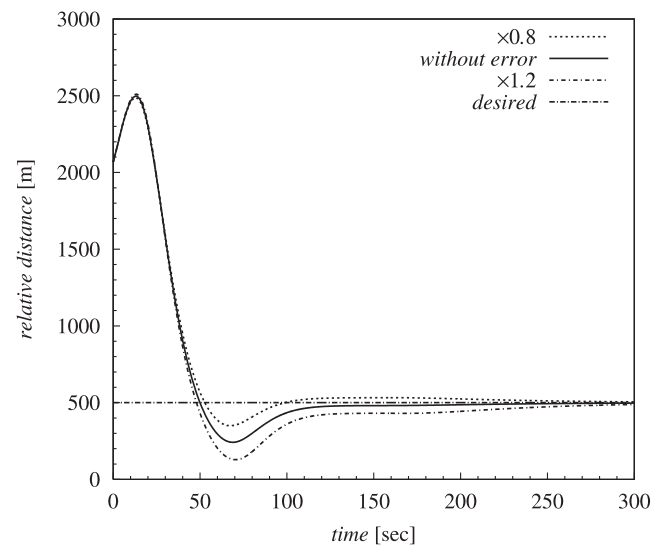

第 17 図 相対距離の時間履歴 $\left(C_{V}-21\right.$, 初期位置誤差大 $)$

対距離が大きい場合の初期設定は, 第 3 表のとおりであり, 前述のシミュレーションと異なる部分を下線で示している。 その他の設定は前述のシミュレーションと同様である。第 17 困に, $C_{V}-21$ を用いた場合の相対距離の時間履歴を示 す。困中の凡例は, 前述のものと同様である。 シミュレー ション開始当初の相対距離が, 約 $2000[\mathrm{~m}]$ となっており, 前述のシミュレーションの約 2 倍となっているが, この場 合でも, 良好な追従性, 収束性を示している。初期相対距 離が小さい場合の初期設定は，第 4 表のとおりであり，第 18 図は， $C_{V}-21$ を用いた場合の相対距離の時間履歴であ る. シミュレーション開始当初の相対距離が, 約 $400[\mathrm{~m}]$ と なっており，目標とする相対距離を下回っているが，この 場合でも，他ケース同様，良好な収束性を示している。紙 面の都合で割愛したが， $C_{V}-22$ を用いた場合でも，同様に 良好な追従性，収束性を示した。

\section{6. 結 論}

前論文で述べた速度距離制御では, 空力推定誤差や目標 機の定常加速度または定常旋回等により, 相対距離に定常 偏差を生じるという問題があった。本論文では，この問題 を解決するために前論文で述べた制御系に積分器を付加し た PI 制御系を提案し，その制御ゲインの決定法を示した。 シミュレーションにより, 本論文において考案した速度距 離制御と，それに関連する制御ゲインの決定法は有効であ

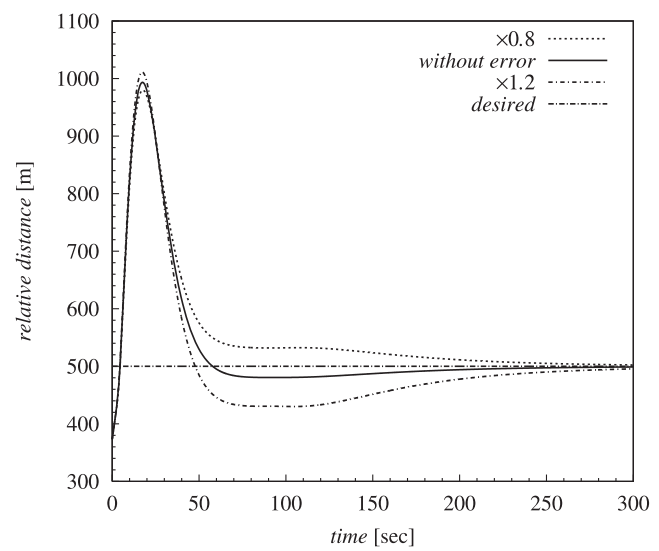

第 18 図 相対距離の時間履歴 $\left(C_{V}-21\right.$, 初期位置誤差小)

り，定常偏差の問題は解決し，良好な追随性を示すことを 明らかにした。

\section{参 考 文 献}

1) Ochi, Y. and Kominami, T.: Flight Control for Automatic Aerial Refueling via PNG and LOS Angle Control, Proceedings of GN \& C Conference, AIAA Paper 2005-6268, California, AIAA, 2005.

2）榎本圭祐，山崎武志，高野博行，馬場順昭：逆ダイナミクス法を 用いた追随飛行無人航空機の速度制御系設計，日本航空宇宙学会 論文集， 57 (2009), pp. 354-362.

3) Machol, R. E., Tanner, W. P., Jr. and Alexander, S. N.: Chap. 19, Guidance, System Engineering Handbook, Howe, R. M. ed., McGraw-Hill Book Company, New York, 1965, pp. 19-1-19-25.

4) Menon, P. K. A., Badgett, M. E., Walker, R. A. and Duke, E. L.: Nonlinear Flight Test Trajectory Controllers for Aircraft, J. Guid. Control Dynam., 10 (1987), pp. 67-72.

5) Lane, S. H. and Stengel, R. F.: Flight Control Design Using Non-Linear Inverse Dynamics, Automatica, 24 (1988), pp. 471-483.

6) Ochi, S., Takano, H. and Baba, Y.: Flight Trajectory Tracking System Applied to Inverse Control for Aerobatic Maneuvers, Inverse Problems in Engineering Mechanics III, Elsevier Science Ltd., Nagano, 2002, pp. 337-344.

7) Yamasaki, T., Sakaida, H., Enomoto, K., Takano, H. and Baba, Y.: Robust Trajectory-Tracking Method for UAV Guidance Using Proportional Navigation, Proceedings of International Conference on Control, Automation and Systems, Seoul, 2007, pp. 1404-1409.

8) Yamasaki, T., Enomoto, K., Tanaka, D., Takano, H. and Baba, Y.: Automatic Control for Chase Aircraft, KSAS Int. J., 7 (2006), pp. 145-154.

9) Enomoto, K., Yamasaki, T., Takano, H. and Baba, Y.: Guidance and Control System Design for Chase UAV, Proceedings of GN \& C Conference, AIAA Paper 2008-6842, Honolulu, Hawaii, AIAA, 2008.

10）馬場順昭, 高野博行 : 非線形飛行経路制御系の誘導ゲインの決定, 日本航空宇宙学会論文集, 47 (1999), pp. 449-456.

11) Snell, S. A.: Preliminary Assessment of the Robustness of Dynamic Inversion Based Flight Control Laws, Proceedings of GN \& C Conference, AIAA Paper 92-4330-CP, Hilton Head Island, AIAA, 1992, pp. 206-216.

12) 加藤寞一郎, 大屋昭男, 柄沢研治：航空機力学入門, 東京大学出 版会，東京， 1982

13) Gilbert, W. P., Nguyen, L. T. and Van Gunst, R. W.: Simulator Study of the Effectiveness of an Automatic Control System Designed to Improve the High-Angle-of-Attack Characteristics of a Fighter Airplane, TN D-8176, NASA, 1976. 